\title{
UJI EFEKTIVITAS KRIM PELEMBAB YANG MENGANDUNG GEL DAUN LIDAH BUAYA (Aloe vera Linn.) DAN ETIL VITAMIN C
}

\author{
${ }^{1}$ Ratih Aryani, ${ }^{2}$ Anita Anggriani, ${ }^{2}$ Sismayati, ${ }^{2}$ Mutiara Hartiwan, ${ }^{2}$ Sani Nurlela \\ ${ }^{1}$ Program Studi Farmasi, Fakultas MIPA, Universitas Islam Bandung, Jawa Barat, Indonesia \\ ${ }^{2}$ Stikes Bakti Tunas Husada Tasikmalaya, Jawa Barat, Indonesia \\ 1e-mail : ratih_aryani@ymail.com
}

\begin{abstract}
ABSTRAK
Lidah buaya (Aloe vera Linn.) merupakan salah satu tanaman yang dapat meningkatkan kelembaban kulit, merangsang fibroblas yang memproduksi kolagen dan elastin. Etil vitamin $\mathrm{C}$ merupakan turunan dari vitamin $\mathrm{C}$ yang lebih stabil sebagai antioksidan serta sebagai booster pembentukan kolagen. Penelitian ini bertujuan membuat sediaan krim pelembab gel lidah buaya yang telah dikeringkan dengan metode freeze drying dan etil vitamin $\mathrm{C}$ untuk memperbaiki kekeringan pada kulit tumit kaki. Merupakan penelitian eksperimental dengan metode Pretest-Posttest Control Group Design, dibuat 5 jenis formula, F0 (basis) dan 4 formula lainnya adalah kombinasi variasi konsentrasi gel daun lidah buaya dan etil vitamin $\mathrm{C}$, berturut-turut F1 (3\%,3\%), F2 (5\%,3\%), F3 (3\%,5\%), F4 (5\%,5\%). Evaluasi sediaan meliputi organoleptik, homogenitas, $\mathrm{pH}$, viskositas, uji sentrifugasi, cycling test, uji iritasi, dan uji efektivitas. Hasil menunjukkan bahwa seluruh formula memenuhi parameter sediaan yang baik dan tidak mengiritasi kulit sukarelawan. Uji efektivitas kelembaban menggunakan alat skin moisture meter analyzer FCM-1 selama 28 hari pada kulit tumit kaki yang pecah-pecah sukarelawan menunjukkan bahwa terdapat perbedaan kelembaban kulit sebelum dan sesudah diberikan perlakuan adalah pada F0 (6,94\%); F1 (46,01\%); F2 (61,27\%); F3 (64,34\%); dan F4 $(40,80 \%)$. Sediaan F3 merupakan formula yang paling baik dengan persentase kenaikan kelembaban paling tinggi, dengan nilai kelembaban awal dari 26,47\% menjadi 43,50\%.
\end{abstract}

Kata kunci: Aloe vera, etil vitamin C, pelembab, krim

\section{ABSTRACT}

Aloe vera (Aloe vera Linn.) is a plant that can improve skin moisture and enhance fibroblast which produces collagen and elastin. Ethyl ascorbic acid is a derivative of vitamin $\mathrm{C}$ is more stable as an antioxidant, can booster formation of collagen. The objective of this research was making the preparation of Aloe vera leaf gel (dried by freeze drying method) and ethyl ascorbic acid in moisturizing cream for foot heel dryness. This research was an experimental method using Pretest-Posttest Control Group Design, there were five types of formula, F0 (base) and four formulas with different combinations of dried Aloe vera leaf gel and ethyl ascorbic acid were formulated such as F1 (3\%,3\%), F2 (5\%,3\%), F3 (3\%,5\%), and F4 $(5 \%, 5 \%)$. Evaluation of preparations included organoleptic, homogeneity, $\mathrm{pH}$, viscosity, centrifugation test, cycling test, irritation test and effectivity test. For all formula showed good result and did not irritate volunteer skin. Effectivity test on increasing volunteers cracked heels moisture for 28 days was done by using FCM-1 skin moisture meter analysis, and showed skin moisture improvement results, F0 (6,94\%); F1 (46,01\%); F2 (61,27\%); F3 $(64,34 \%)$; and F4 (40,80\%). F3 is the best formula with the highest percentage of moisture, initial moisture is $26,47 \%$ to $43,50 \%$.

Keywords: Aloe vera, ethyl ascorbic acid, moisturizer, cream 


\section{PENDAHULUAN}

Kulit yang kering dan pecah-pecah pada tumit kaki terjadi akibat hilangnya lipid kulit dan faktor pelembab alami. Tumit kaki yang pecah-pecah terlihat kurang menarik dan dapat menimbulkan rasa nyeri saat berjalan jauh, sehingga kesehatan kaki sangat penting bagi kenyamanan tubuh (Salika, 2010; Juliani, 2007). Kulit kering menggambarkan abnormalitas stratum korneum yang berfungsi sebagai pelindung terhadap kehilangan air karena penguapan yang berlebihan dan pengaruh lingkungan. Pada kondisi normal, stratum korneum mengandung sekitar 30\% air. Menurunnya kapasitas retensi air pada stratum korneum dengan kandungan air kurang dari $10 \%$ mengakibatkan fungsi kulit terganggu. Hilangnya kelembaban stratum korneum dan matriks antar sel menyebabkan kulit kering, kasar bersisik dan retak (Dewi, 2010; Dange dan Grandhi, 2009). Untuk memperbaiki kekeringan kulit dapat dilakukan dengan mempertahankan hidrasi epidermis, dan memperbaiki elastisitas kulit. Oleh karena itu dibuatlah sediaan krim yang mengandung bahan pelembab dan antioksidan. Pelembab dapat meningkatkan kadar air stratum korneum dan hydrating agent, sehingga dapat mereduksi tanda dan gejala kulit kering, bersisik, kasar serta membuat permukaan kulit menjadi halus dan lembut (Schliemann dan Elsner, 2007). Antioksidan adalah bahan yang dapat mencegah, menghambat dan mengendalikan reaksi oksidasi dari radikal bebas yang menyebabkan kerusakan struktural kulit, mengurangi elastisitas, ketahanan dan kelenturan serta meningkatnya peradangan (Winarsi, 2007).

\section{Lidah buaya (Aloe vera Linn.)} merupakan salah satu bahan alam yang dapat berfungsi sebagai pelembab kulit, penyembuh luka, antioksidan, antiinflamasi, antiageing, dan antiseptik (Surjushe, $d k k$., 2008; Sutrisno, 2014). Daging (gel) lidah buaya mengandung air, polisakarida (glucomannan dan acemannan), karboksipeptidase, magnesium, zink, kalsium, glukosa, kolesterol, asam salisilat, gamma linolenic acid (GLA), vitamin A, C, E, lignin, saponin, sterol dan asam amino. Kandungan Mukopolisakarida pada lidah buaya dapat membantu dalam mengikat kelembaban kulit, merangsang fibroblas yang memproduksi kolagen dan elastin sehingga membuat kulit lebih elastis (Surjushe dkk., 2008). Ekstrak lidah buaya 3\% dapat menurunkan kadar transepidermal water loss 
(TEWL) dan meningkatkan kandungan air dalam stratum korneum (Akhtar dkk., 2001).

Etil vitamin $\mathrm{C}$ merupakan turunan dari vitamin $\mathrm{C}$ yang lebih stabil dan dimetabolisme sebagai vitamin $\mathrm{C}$ murni dalam tubuh makhluk hidup. Vitamin $\mathrm{C}$ merupakan nutrisi penting yang diperoleh dari asupan secara eksogen, berfungsi sebagai antioksidan yang dapat menangkal radikal anion superoksid, radikal hidroksil, hipoklorit, singlet oksigen, radikal thiyl dan radikal peroksil yang larut air serta booster pembentukan kolagen yang penting untuk mempertahankan struktur kulit (Thiele, dkk., 2000). Vitamin C berpotensi sebagai antiinflamasi. Aplikasi topikal 5\% vitamin $\mathrm{C}$ dapat meningkatkan prokolagen 1 dan 3 (Nusgens dkk., 2001). Sedangkan penelitian Sauermann, dkk (2004), menunjukkan bahwa 3\% vitamin $\mathrm{C}$ dapat meningkatkan kepadatan dermal papila pada kulit lansia.

Telah banyak penelitian mengenai lidah buaya sebagai pelembab kulit, namun kombinasinya dengan etil vitamin $\mathrm{C}$ belum pernah dilakukan untuk menambah efektivitasnya dalam sediaan dalam mengobati tumit yang pecah-pecah. Oleh karena itu pada penelitian ini akan dilakukan formulasi dan uji efektivitas sediaan krim kombinasi gel lidah buaya dan etil vitamin $\mathrm{C}$ dalam mengobati masalah kekeringan tumit kaki. Sehingga diharapkan menjadi sediaan yang ideal yang mampu meremajakan kekeringan kulit tumit kaki tanpa menimbulkan efek iritasi.

\section{METODE PENELITIAN}

\subsection{Alat dan Bahan}

Neraca analitik (Shimadzu AUY-220), blender (Philips), freeze drier, oven (Memmert), viscometer (Brookfield), $\mathrm{pH}$ meter, skin moisture analyzer FCM-1, dan alat-alat gelas laboratorium. Gel Lidah buaya (Aloe vera Linn) diperoleh dari Kota Tasikmalaya dan di determinasi di Fakultas Biologi Universitas Jenderal Soedirman, etil vitamin $\mathrm{C}$ dan basis krim diperoleh dari PT. Beauty Essence.

\subsection{Penyiapan Serbuk Gel Lidah Buaya}

Daun lidah buaya dikuliti, dikeluarkan gel, getah dan lendir, kemudian dikeringkan dengan menggunakan metode pengeringan beku atau freeze drying untuk mengantisipasi kerusakan komponen seperti terdegradasi atau terdekomposisi baik oleh suhu, reaksi 
oksidasi, maupun reaksi pencoklatan tangan kanan diolesi dengan sediaan. enzimatik (Pujihastuti, 2009).

\subsection{Pemeriksaan Parameter Serbuk dan Skrining Fitokimia}

Pemeriksaan parameter serbuk meliputi organoleptik, kadar abu total, dan susut pengeringan. Hasil dapat dilihat pada Tabel 1. Sedangkan skrining fitokimia serbuk gel lidah buaya dapat dilihat pada Tabel 2 .

\subsection{Formulasi Krim Pelembab}

Dilakukan formulasi krim dengan basis yang paling baik ditinjau berdasarkan stabilitas uji sentrifugasi, tekstur dan konsistensinya. Rancangan formula krim dapat dilihat pada Tabel 3 .

\subsection{Evaluasi Krim Pelembab}

Evaluasi sediaan meliputi Organoleptik, homogenitas, $\mathrm{pH}$, viskositas, uji tipe emulsi, uji sentrifugasi, cycling test. Hasil dapat dilihat pada Tabel 4.

\subsection{Uji Iritasi}

Uji iritasi dan kepekaan pada kulit normal dilakukan selama 15 menit setelah diaplikasikan kepada 30 responden yang mempunyai kulit normal dengan persetujuan komite ETIK. Punggung tangan kiri diolesi sediaan basis tanpa zat aktif, dan punggung 
(Trookman dkk., 2009; Pranajaya, 2014). pengukuran sisa ekstrak setelah dilakukan Hasil dapat dilihat pada Tabel 7.

\section{HASIL DAN PEMBAHASAN}

\subsection{Pemeriksaan Parameter Kualitas Serbuk}

Kadar abu dinyatakan sebagai mineral yang terkandung dalam suatu bahan. Sedangkan susut pengeringan menyatakan pengeringan, jika bahan tidak mengandung minyak menguap/ atsiri dan sisa pelarut organik menguap maka dinyatakan identik dengan kadar air (Ratnani dkk., 2015). Pada hasil pengujian nilai kadar abu dan susut pengeringan sedikit melebihi batas yang telah ditetapkan pada pustaka.

Tabel 1. Hasil Pengujian Parameter Serbuk

\begin{tabular}{|c|c|c|}
\hline Parameter & Hasil & Pustaka* \\
\hline Warna serbuk & Putih kekuningan & Kuning \\
\hline Kadar abu total & 0,0274 & Maksimum $2 \%$ \\
\hline Susut pengeringan & 0,1247 & Maksimum $12 \%$ \\
\hline
\end{tabular}

*) WHO Monographs on selected medicinal plants, 1999

Tabel 2. Hasil Pengujian Skrining Fitokimia

\begin{tabular}{ll}
\hline \hline \multicolumn{1}{c}{ Uji } & Hasil Pengamatan \\
\hline \hline $\begin{array}{l}\text { Alkaloid, saponin, } \\
\text { steroid, triterpenoid, } \\
\text { tanin, polifenol }\end{array}$ & - \\
\hline $\begin{array}{l}\text { Kuinon, monoterpenoid, } \\
\text { seskuiterpenoid, } \\
\text { antrakuinon, flavonoid }\end{array}$ \\
\hline \hline
\end{tabular}

Keterangan :

$(+)=$ hasil positif untuk keberadaan senyawa

$(-)=$ hasil negatif untuk keberadaan senyawa 


\subsection{Formulasi krim pelembab}

Sebelum dilakukan formulasi sediaan krim pelembab, dilakukan optimasi basis dan dipilih basis yang terbaik berdasarkan stabilitas dengan uji sentrifugasi, tekstur dan konsistensi.

Tabel 3. Formulasi Krim Pelembab

\begin{tabular}{|c|c|c|c|c|c|}
\hline \multirow{2}{*}{ Komposisi } & \multicolumn{5}{|c|}{ Jumlah (\% b/b) } \\
\hline & F0 & F1 & $\mathbf{F 2}$ & $\mathbf{F 3}$ & F4 \\
\hline Serbuk lidah buaya & 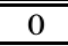 & 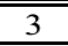 & 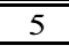 & 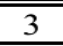 & 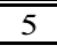 \\
\hline Etil Vitamin C & 0 & 3 & 3 & 5 & 5 \\
\hline BHT & 0,5 & 0,5 & 0,5 & 0,5 & 0,5 \\
\hline Poligliseril-3-Metilglukosa distearat & 8 & 8 & 8 & 8 & 8 \\
\hline Setil alkohol & 2 & 2 & 2 & 2 & 2 \\
\hline Neopentil Glikol Diheptanoat & 3 & 3 & 3 & 3 & 3 \\
\hline Capric Trigliserida & 5 & 5 & 5 & 5 & 5 \\
\hline Fenoksietanol & 2 & 2 & 2 & 2 & 2 \\
\hline Gliserin & 2 & 2 & 2 & 2 & 2 \\
\hline Propilen glikol & 5 & 5 & 5 & 5 & 5 \\
\hline Tween 80 & 1 & 1 & 1 & 1 & 1 \\
\hline Akrilat & 2 & 2 & 2 & 2 & 2 \\
\hline Aqua DM & & & id 10 & & \\
\hline
\end{tabular}

Keterangan : F0 = Formula basis, F1 = Formula 1, F2 = Formula 2, F3 = Formula 3, F4 = Formula 4

\subsection{Evaluasi Sediaan Krim}

Dari sediaan krim yang telah dibuat dilakukan uji iritasi pada responden, hasil menunjukkan bahwa seluruh sediaan tidak mengiritasi karena tidak menunjukkan gejala kemerahan pada kulit punggung tangan yang telah diolesi sediaan sehingga sediaan aman untuk digunakan. Selanjutnya dilakukan evaluasi selama 1 bulan penyimpanan pada suhu kamar. Pengamatan organoleptis secara keseluruhan tidak menunjukkan perubahan maupun pemisahan fasa dan nilai $\mathrm{pH}$ berkisar 5,3-7,0. Sediaan memiliki homogenitas yang baik yaitu tidak terdapat partikel-partikel kasar secara visual. Uji tipe emulsi dilakukan dengan metode pengenceran fasa luar yakni dengan menambahkan air, hasil menunjukkan bahwa semua formula larut dalam air sehingga tipe krim adalah emulsi minyak dalam air (m/a). Uji sentrifugasi dilakukan pada kecepatan $3750 \mathrm{rpm}$ selama 5 jam, bertujuan untuk mengetahui kestabilan emulsi pada krim selama masa penyimpanan karena terdapat pengaruh gaya gravitasi yang dapat mempengaruhi kestabilan krim. Hasil evaluasi menunjukkan bahwa semua formula tidak mengalami pemisahan fasa. Uji tipe aliran sediaan menunjukkan tipe aliran pseudoplastis 
dikarenakan mengalami penurunan viskositas ketika laju geser ditingkatkan (Dianingsih dkk., 2016). Untuk pengujian cycling test dilakukan selama 6 siklus pada suhu $4^{\circ} \mathrm{C}$ dan suhu $40 \pm 2^{\circ} \mathrm{C}$, masing-masing selama 24 jam
(Silalahi dkk., 2015). Hasil dapat dilihat pada Tabel 4, menunjukkan bahwa semua formula tidak terjadi pembentukan kristal dan tidak mengalami pemisahan fasa.

Tabel 4. Hasil Uji Cycling Test

\begin{tabular}{|c|c|c|c|c|c|c|}
\hline \multirow{2}{*}{ Sediaan } & \multicolumn{2}{|c|}{ Siklus ke-0 } & \multicolumn{4}{|c|}{ Siklus ke-6 } \\
\hline & Warna & pH & Warna & $\mathbf{p H}$ & Kristalisasi & Pemisahan Fase \\
\hline Formula 0 (Basis) & Putih & 7,0 & Putih & 7,0 & Tidak terjadi & Tidak terjadi \\
\hline Formula 1 & \multirow{4}{*}{$\begin{array}{l}\text { Krem (putih } \\
\text { kekuningan) }\end{array}$} & 5,3 & \multirow{4}{*}{$\begin{array}{l}\text { Krem (putih } \\
\text { kekuningan) }\end{array}$} & 5,3 & \multirow{4}{*}{ Tidak terjadi } & \multirow{4}{*}{ Tidak terjadi } \\
\hline Formula 2 & & 5,3 & & 5,3 & & \\
\hline Formula 3 & & 5,3 & & 5,3 & & \\
\hline Formula 4 & & 5,3 & & 5,3 & & \\
\hline
\end{tabular}

\subsection{Uji Efektivitas Krim Pelembab}

Tabel 5. Hasil Uji efektivitas Krim Pelembab

\begin{tabular}{|c|c|c|c|c|c|c|}
\hline \multirow[t]{2}{*}{ Formula } & \multicolumn{5}{|c|}{$\begin{array}{c}\text { Nilai Kelembaban (\%), Minggu ke- } \\
\text { Rata-rata } \pm \text { SD }\end{array}$} & \multirow[t]{2}{*}{ Total Peningkatan (\%) } \\
\hline & $\mathbf{0}$ & 1 & 2 & 3 & 4 & \\
\hline F0 (Basis) & $2,80 \pm 0,00$ & $25,20 \pm 0,44$ & $25,53 \pm 0,67$ & $25,82 \pm 0,40$ & $26,52 \pm 0,68$ & 6,94 \\
\hline F1 & $28,08 \pm 2,16$ & $35,07 \pm 1,76$ & $36,65 \pm 1,23$ & $37,73 \pm 1,47$ & $41,00 \pm 4,85$ & 46,01 \\
\hline F2 & $25,10 \pm 0,74$ & $28,05 \pm 1,26$ & $30,50 \pm 1,71$ & $36,33 \pm 5,03$ & $40,48 \pm 4,7$ & 61,27 \\
\hline F3 & $26,47 \pm 0,91$ & $32,57 \pm 3,33$ & $33,97 \pm 4,55$ & $36,80 \pm 4,83$ & $43,50 \pm 6,78$ & 64,34 \\
\hline F4 & $24.95 \pm 0,37$ & $28,33 \pm 1,48$ & $29,80 \pm 1,78$ & $32,20 \pm 2,65$ & $35,13 \pm 3,66$ & 40,8 \\
\hline
\end{tabular}

Tabel 6. Skala kelembaban alat Skin Moisture Analyzer FCM-1

\begin{tabular}{ccc}
\hline \hline$\frac{\text { Kelembaban (\%) }}{2}$ & $\frac{\text { Deskripsi }}{\text { Kurang lembab }}$ \\
\hline \hline $\mathbf{4 0 - 6 0}$ & $\frac{\text { Lembab }}{200}$ & Sangat lembab \\
\hline \hline
\end{tabular}


Nilai efektivitas krim pelembab dapat dilihat dari kenaikan persentase kelembaban yang dihitung berdasarkan selisih nilai kelembaban yang dihasilkan pada alat skin moisture analyzer sebelum dan sesudah perlakuan dan dibandingkan dengan nilai kelembaban sebelum perlakuan pemberian sediaan. Terlihat bahwa kenaikan kelembaban yang paling baik adalah pada F3, nilai kelembaban kulit sukarelawan meningkat sebesar $64,34 \%$ dari nilai awal sebelum perlakuan adalah 26,47\% sehingga setelah perlakuan nilai kelembaban kulit menjadi 43,50\%, nilai tersebut menunjukkan bahwa berdasarkan skala nilai kelembaban alat skin moisture

\section{KESIMPULAN}

Dari penelitian yang telah dilakukan dapat dilihat bahwa sediaan F3 (3\% lidah buaya dan 5\% etil vitamin C) merupakan sediaan terbaik yang dapat meningkatkan kelembaban pada kulit tumit kaki yang kering hingga $64,34 \%$.

\section{DAFTAR PUSTAKA}

Akhtar N., Khan BA, Mahmood T, Khan HMS, Iqbal M dan Bashir S, 2011. analyzer FCM-1termasuk kedalam kulit yang lembab disamping itu kulit tumit kaki sukarelawan yang diberikan sediaan F3 menunjukkan tekstur kulit yang baik yaitu sudah tidak terlihat pecah-pecah lagi. Sehingga konsentrasi 3\% ekstrak lidah buaya dapat menurunkan kadar transepidermal water loss (TEWL) dan meningkatkan kandungan air dalam stratum korneum sedangkan Vitamin C sangat penting untuk biosintesis kolagen, yaitu berfungsi sebagai kofaktor untuk enzim prolisil dan lisil hidroksilase yang merupakan enzim yang bertanggung jawab untuk menstabilkan taut silang molekul kolagen (Akhtar dkk., 2001; Burke, 2007; Telang, 2013).

Formulating Development and Moisturising Effects of a Topical Cream of Aloe vera Extract. Isindexing, 5(3):1149-1157.

Burke KE., 2007. Interaction of vitamins C and $\mathrm{E}$ as Better Cosmeceuticals, Dermatol Ther, 20(5):314-21.

Dange SV., dan Grandhi S., 2009. Clinical efficacy of Foot Care Cream in the management of foot cracks. Indian Medical Journal, 103(10):350-353.

Dewi DAR.,2010. Penambahan Saccharide Isomerates 5\% Dalam Formulasi Pelembab Meningkatkan Hidrasi Kulit Lebih Tinggi 
Dibandingkan Pelembab Biasa (Tesis). Denpasar: Program Pascasarjana, Universitas Udayana.

Dianingsih N, 2016. Sifat Reologi dan Stabilitas Fisiki Minuman Emulsi Minyak Sawit. J. Teknol. Dan Industri Pangan, 27(2):165-174.

Juliani S, 2007. Formulasi Dan Uji Efek Krim Pelembab Untuk Mengatasi Xerosis Pada Tumit Kaki (Skripsi). Bansung: Program Studi Sains dan Teknologi Farmasi, Sekolah Farmasi, Institut Teknologi Bandung.

Nusgens BV., 2001. Topically Applied Vitamin C Enhances the mRNA Level of Collagens I and III, Their Processing Enzymes and Tissue Inhibitor of Matrix Metalloproteinase 1 in the Human Dermis. JID, 116:853-859.

Padmadisastra Y., Syaugi A., dan Anggia S., 2007. Formulasi Sediaan Salep Antikeloidal Yang Mengandung Ekstrak Terfasilitasi Panas Microwave Dari Herba Pegagan (Centella asiatica (L.) Urban. Seminar Kebudayaan Indonesia Malaysia Kualalumpur.

Pranajaya T, 2014. Perbedaan Kelembaban Kulit Tangan Sebelum Dan Sesudah Cuci Tangan Bedah Menggunakan Povidone Iodine 7,5\% Dan Chlorhexidine Gluconate 4\% Di Central Operation Theatre (Cot) Lantai 3 Rsup Dr. Hasan Sadikin Bandung (Skripsi). Bandung: Fakultas Keperawatan, Universitas Padjadjaran.

Pujihastuti I, 2009. Teknologi pengawetan Buah Tomat Dengan Metode Freeze Drying. J Metana, 6(1):1-8.
Ratnani RD., Hartati I., Anas Y., Endah D., dan Khilyati DD, 2015. Standarisasi spesifik dan non spesifik ekstraksi hidrotropi andrographolid dari sambiloto (Andrographis paniculata). Prosiding Seminar Nasional Peluang Herbal Sebagai Alternatif Medicine. Fakultas Farmasi Universitas Wahid Hasyim.

Salika, 2010. Serba Serbi Kesehatan Perempuan: Apa Yang Perlu Kamu Tahu Tentang Tubuhmu, Editor: Dewi Fita. Jakarta : Bukune.

Schliemann S, dan Elsner P, 2007. Skin Protection: Practical Application in The Occupational Setting. Switzerland: Reinhart Duck.

Sauermann K, Jaspers S, Koop U, dan Wenck H, 2004. Topically Applied Vitamin C Increases The Density Of Dermal Papillae In Aged Human Skin. BMC Dermatology, 4:13.

Surjushe A, Vasani R, dan Saple DG, 2008. Aloe vera: a Short Review. Indian J Dermatol, 53(4):163-166.

Sutrisno L, 2014. Formulasi Sediaan Pelembab Ekstrak Lidah Buaya (Aloe vera L.) Dengan Kombinasi Gliserin Dan Propilen Glikol Dalam Basis Vanishing Cream (Skripsi). Surabaya: Program Studi S1 farmasi, Fakultas Farmasi, Universitas Katolik Widya Mandala.

Telang PS, 2013. Vitamin C In Dermatology. Indian Dermatol Online J, 4(2):143-146.

Thiele JJ., Dreher F., Packer L., 2000. Antioxidant Defense System in Skin, Cosmoceutical Drugs Vs Cosmetics, Editor Peter Elsner dan Howard. 
Maibach. New York : Marcel Dekker Inc.

Trookman NS., Rizer RL., Ford R., Mehta R., dan Gotz V., 2009. Clinical Assessment of a Combination Lip Treatment to Restore Moisturization and Fullness. $J$ Clin Aesthet Dermatol, 2(12): 44-48.

WHO, 1999.Aloe and Aloe vera gel. WHO Monographs on selected medicinal plants. Vol. 1. Geneva, Switzerland: World Health Organization; pp. 3349 (available from

http://apps.who.int/medicinedocs/ en/d/Js2200e/5.html).

Winarsi H, 2007. Antioksidan Alami Dan Radikal Bebas. Yogyakarta: Penerbit Kanisius. 